\title{
Remaining life assessment of high temperature components using threshold stress concept
}

\section{RAGHUBIR SINGH}

Materials Evaluation Division, National Metallurgical Laboratory, Jamshedpur 831 007, India

\begin{abstract}
The paper first presents global experience, including that of our laboratory, mainly with power plant components to show that it is possible to extend the life of some critical components 2-3 fold over the design life. Different approaches for remaining life assessment are also briefly discussed.

It appears that the main creep damage in so far as $\mathrm{Cr}-\mathrm{Mo}$ and $\mathrm{Cr} \sim \mathrm{Mo}-\mathrm{V}$ steels are concerned, is an accumulation of creep strain. Hence, this paper suggests a new approach for creep life prediction based on threshold stress concept and stress-strain rate relationship. The approach is based on the analysis of creep and hot tensile data generated on a popular $1 \mathrm{Cr}-0.3$ Mo-0.25 V steel in the service exposed and the virgin states and also on samples with a wide range of microstructures prepared from the virgin states. A summary of the main finding leading to development of a new approach has been given.
\end{abstract}

Keywords. Creep resistant steels; creep strain damage; threshold stress; remaining life.

\section{Introduction}

Low alloy ferritic steels, $1 \mathrm{Cr}-0.5 \mathrm{Mo}, 2.25 \mathrm{Cr}-1 \mathrm{Mo}-0.5 \mathrm{Cr}-\mathrm{Mo}-\mathrm{V}$, are extensively used for high temperature applications in the power, chemical and oil industries. This is because they have very good elevated temperature creep strength together with good resistance to oxidation and hydrogen embrittlement. These steels have been used in power industries for components such as turbine rotors, cylinders, steam chests, steam pipes, headers etc. The typical service temperature and stress in the power industry are about $550^{\circ} \mathrm{C}$ and $50 \mathrm{MPa}$ respectively. Thus the components operate in the temperature range where the creep is the main life limiting factor. Prolonged service exposure of boiler and turbine components could lead to degradation of their mechanical properties and hence these are designed for a certain definite life (10-20 years). In many cases component replacement after design life expiry is not necessary due to 'conservatism' at the design stage and hence, calls for methods for full life exploitation. In other cases, however, operating conditions can be more burdensome than envisaged by the designer and hence plant integrity assessment may be required before the design life is 
reached to ensure safety. Thus, the need for remaining life assessment both for economic and safety cannot be obviated.

The available approaches for creep life prediction can be broadly classified into the following (Cane \& Townsend 1983; Viswanath 1989):

- operational parameter approach;

- post-service examination approach.

The first approach depends on the evaluation of the service temperature/stress history for a given component. Once the history is known then combining it with the lower bound value of the standard material data and the life fraction rule an estimate of remaining life can be obtained as illustrated in figure 1 . However, this approach has not been fully successful because of several limitations:

- The operational data with requisite precision are not always available;

- standard material data have a wide scatter and often cannot be reliably extrapolated to the rather low operating stresses;

- Life fraction rule used in this approach is not always applicable.

Thus the approach at best can serve the purpose of obtaining a very rough estimate of creep life.

The second approach based on direct evaluation of the component after prolonged service exposure is undoubtedly more accurate and also does not require detailed knowledge of the service history. Hence it is widely used. Among the numerous techniques available for post-service evaluation listed in table 1 the accelerated stress rupture testing is the most common. In order to obtain results within a reasonable period of time, these tests have to be accelerated by tesing: either at higher stresses or at high temperatures or both. The short-term rupture data so obtained, are extrapolated to ascertain long-term life at lower stresses/temperature as illustrated in figure $2(a, b)$. This approach has the following limitations.

- being empirical its validity is limited to the domain of available database, i.e. the short-term data have only limited extrapolation capacity;

- The procedure is time consuming and expensive.

On the whole, the method gives a first estimate of the life.

It is important to recall here that the critical components are allowed to undergo only a limited creep strain (1-2\%) and there are evidences (Wufee 1983; Weber 1993)

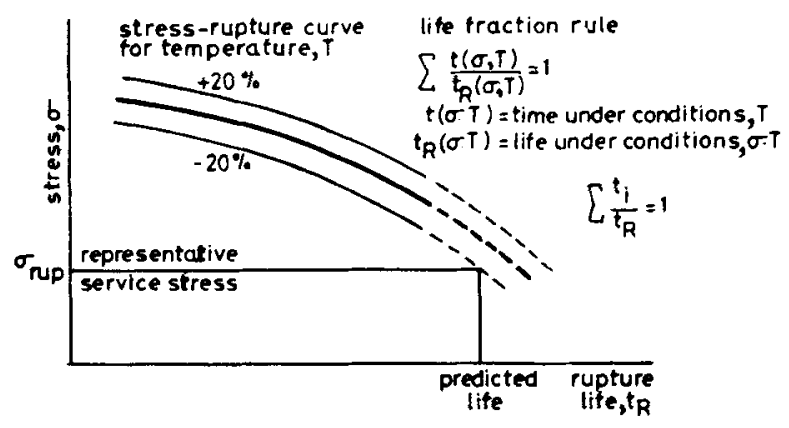

Figure 1. Schematic representation of operational parameter approach (Cane \& Townsend 1983). 
Table 1. Techniques available for post-service evaluation.

\begin{tabular}{|c|c|}
\hline Technique & Comments \\
\hline \multicolumn{2}{|l|}{ Physical: } \\
\hline $\begin{array}{l}\text { Density, resistivity, magnetic } \\
\text { permeability, small-angle neutron } \\
\text { scatter }\end{array}$ & $\begin{array}{l}\text { May be suitable for cavity } \\
\text { assessment }\end{array}$ \\
\hline \multicolumn{2}{|l|}{ Mechanical: } \\
\hline $\begin{array}{l}\text { Tensile (Room temperature), } \\
\text { tensile (hot), hardness, charpy }\end{array}$ & $\begin{array}{l}\text { May be useful for rough } \\
\text { assessment }\end{array}$ \\
\hline $\begin{array}{l}\text { Low-cycle fatigue } \\
\text { Metallographic examination using } \\
\text { acetate replica; micro-sample removal }\end{array}$ & $\begin{array}{l}\text { limited applicability } \\
\text { Useful provided coupled with } \\
\text { creep strength. }\end{array}$ \\
\hline $\begin{array}{l}\text { NDE method: Oxide scale thickness } \\
\text { measurement }\end{array}$ & $\begin{array}{l}\text { Useful if damage mechanism is } \\
\text { oxidation }\end{array}$ \\
\hline Accelerated stress-rupture testing & $\begin{array}{l}\text { Useful provided extrapolation is } \\
\text { done judiciously }\end{array}$ \\
\hline
\end{tabular}

to suggest that the $\mathrm{Cr}-\mathrm{Mo}$ and $\mathrm{Cr}-\mathrm{Mo}-\mathrm{V}$ types of steel can sustain this strain without entering into the tertiary stage.

In view of this it appears to be more appropriate to develop life prediction methodology based essentially on the creep deformation data such as creep rate vs stress relationship particularly when the service stress is lower than the threshold stress as has been proposed by the author (Singh \& Banerjee 1992).

In what follows is a brief presentation of global experience and that of NML about the vital issue of "in-service degradation" mainly to bring into focus the need for creep deformation data base in the low-stress region to:

- determine the threshold stress;

- develop a reliable relationship between creep strain rate-stress for life prediction.

\section{Global experience}

The assessment of accumulated damage and the estimation of remaining life of components particularly of boiler pressure parts has been the subject of intense study for the past several years. A large volume of information has been generated as can be seen in the proceedings of recent conferences (Wufee 1983; Dooley 1987). This information must be critically analysed to evolve a reliable method for predicting remaining life of components. Indeed, this will vary from component to component depending on the operating condition.

In steam power plants, the following components have received special attention for life extension:

- superheater (SH) and reheater ( $\mathrm{RH})$;

- headers;

- main steam pipes;

- superheater and reheater. 


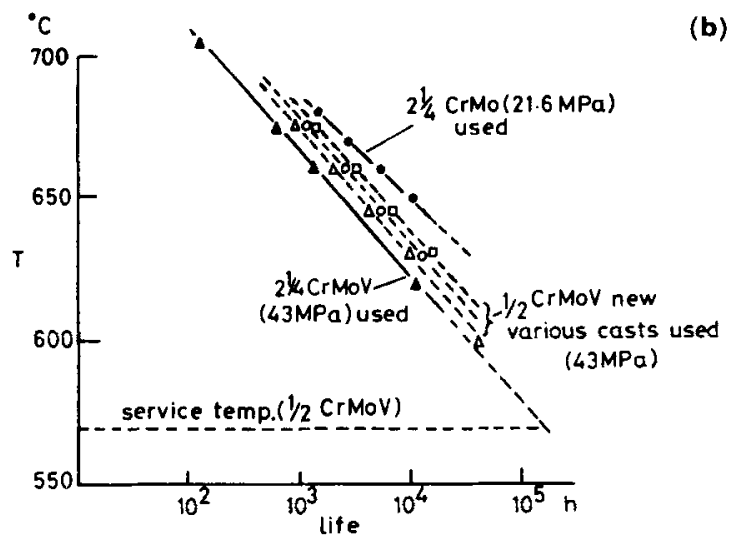

(a)

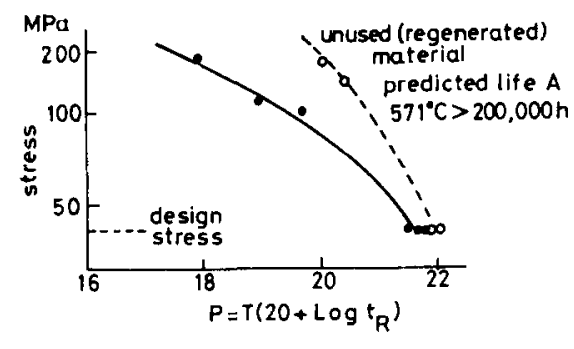

Figure 2. Post service examination approach (Cane and Townsend 1983): (a) stress vs Larson-Miller parameter plots; (b) temperature vs rupture life plots.

SH and RH fail due to one or a combination of the following causes:

- overheating;

- short-term overheat;

- long-term overheat;

- corrosion;

- fire-side corrosion;

- steam-side corrosion;

- stress-corrosion cracking;

- fly-ash erosion;

- exfoliation.

This clearly reveals that life assessment of $\mathrm{SH}$ and $\mathrm{RH}$ shall require a comprehensive approach which takes into account all the factors responsible for the failure. This is outside the scope of this paper. However, some approaches has been discussed in another article of this issue (Ghosh et al 1995).

\section{Header and main steam pipe}

Unlike SH and RH, the headers and steam piping operate fairly under steady state stress and temperature. These are very expensive components and the failure besides causing long-term outages can be catastrophic. Hence, they deserve special attention. 
Header and main steam pipe essentially undergo two processes during service exposure:

- creep deformation under long-term influence temperature/stress;

- change(s) in microstructure and properties under the long-term influence of temperature/stress.

Information on these two aspects is of crucial importance for the life assessment and extension.

\section{Creep deformation in service}

In the coded design, the limit on creep strain rate is $10^{-7} / \mathrm{h}$ and the accumulated creep strain should be less than $1 \%$. That the actual creep rate is much lower than that envisaged at the design stage is borne out by the table 2 (Wufee 1983) and table 3 (Auerkan 1983). It is significant that hardly $0.2 \%$ creep had occurred after the service life of $100,000 \mathrm{~h}$. Though the data given in table 3 do not report the value of accumulated creep strain, the operational time as high as $2,50,000 \mathrm{~h}$ indirectly reflects that the creep rate was much less than 10-7/h. Similar service experience has been widely reported recently (Dooley 1987).

In some of the plants diametrical expansion of the steam pipe is also measured at regular intervals. The expansions are measured at certain pre-fixed locations; the measurements are made along both horizontal and vertical axes. Some such data are shown in figures 3,4 (Weber 1983). These data besides showing that the actual creep rate is generally less than $10-7 / \mathrm{h}$, bring out another important fact: The mode of creep deformation remained essentially the steady state and the tertiary creep had not set in even when the creep strain had nearly touched the prescribed limit of $1 \%$. This is a very useful inoformation from the view-point of life prediction based on the knowledge of the creep rate at the operating stress and temperature. This aspect has been dealt with subsequently. Another interesting point that transpires from figures $3 \& 4$ is that the expansion along horizontal axis is often larger than that along vertical axis.

Table 2. Practical examples of life prediction by the comprehensive analysis method and assessment of results (Wufee 1993)

\begin{tabular}{lccccccccc}
\hline $\begin{array}{l}\text { Name } \\
\text { of pipe } \\
\text { work }\end{array}$ & Material & $\begin{array}{c}\text { Total } \\
\text { operation } \\
\text { duration of } \\
\text { sampling(h) }\end{array}$ & $\begin{array}{c}\text { Life prediction } \\
\text { Stress evaluation }\end{array}$ & $\begin{array}{c}\sigma 10^{5} \\
(\mathrm{MPa})\end{array}$ & $\begin{array}{c}\sigma_{Z S} \\
(\mathrm{MPa})\end{array}$ & $\mathrm{K}$ & $\begin{array}{c}\text { Creep } \\
\text { strain } \\
(\%)\end{array}$ & $\begin{array}{c}\text { Conclusion } \\
\text { (continue } \\
\text { operation } \\
\text { hours) }\end{array}$ & $\begin{array}{c}\text { Operation } \\
\text { duration } \\
\text { up to now } \\
\left(\times 10^{5} \mathrm{~h}\right)\end{array}$ \\
\hline MSP & $12 \mathrm{CrMo}$ & 107675 & 133.3 & 46.4 & 2.9 & $<0.2$ & $10^{5}$ & $\sim 1.9$ \\
MSHS & $15 \mathrm{CrMo}$ & $\sim 137000$ & 109.8 & 46.6 & 2.4 & & $10^{5}$ & $\sim 2.1$ \\
MSP & $12 \mathrm{Cr} 1 \mathrm{MoV}$ & 90000 & 107.8 & 57.2 & 1.9 & 0.15 & $10^{5}$ & $\sim 1.7$ \\
MSP & $12 \mathrm{Cr} 1 \mathrm{MoV}$ & 110660 & 107.8 & 57.2 & 1.9 & 0.15 & $10^{5}$ & $\sim 1.9$ \\
MSP & $12 \mathrm{Cr} 1 \mathrm{MoV}$ & 101794 & 110.8 & 61.8 & 1.8 & 0.13 & $10^{5}$ & $\sim 1.7$ \\
\hline
\end{tabular}

* MSP - main steam pipe; MSHS - main steam header system; $\sigma_{10}:$ stress for rupture in $10^{5} \mathrm{~h}$; $\sigma_{Z S}:$ service hoop stress; $K \quad: \sigma_{10^{s}} / \sigma_{Z S}$ 
Table 3. Inspected steam pipings (Auerkan '1983).

\begin{tabular}{llll}
\hline Plant & $\begin{array}{c}\text { Nominal steam } \\
\text { values } \\
\left({ }^{\circ} \mathrm{C} / \mathrm{MPa}\right)\end{array}$ & Type of material & $\begin{array}{c}\text { Operational time, } \mathrm{h} \\
\text { (design life } \\
100,000 \mathrm{~h})\end{array}$ \\
\hline A & $510^{\circ} / 6$ & $1 \mathrm{Cr}-0.5 \mathrm{Mo}$ & 238,000 \\
B & $480^{\circ} / 6$ & $1 \mathrm{Cr}-0.5 \mathrm{Mo}$ & 250,000 \\
$\mathrm{C}$ & $530^{\circ} / 11.5$ & $1 \mathrm{Cr}-0.5 \mathrm{Mo}$ & 148,000 \\
D & $520^{\circ} / 6$ & $2.25 \mathrm{Cr}-1 \mathrm{Mo}$ & \\
E & $525^{\circ} / 11.5$ & $1 \mathrm{Cr}-0.5 \mathrm{Mo}$ & 156,000 \\
\hline
\end{tabular}

Some reasons suggested for the gap between anticipated and actual creep rate are:

- the mean diameter formula used for calculating hoop stress yields $15 \%$ higher values (Cane 1983).

- the steels used for such critical components have the creep properties better than the 'minimum' property data used for design.

- stress exponent of $\sim 4$ generally used by designers could be higher.

For steam pipes which work under the stipulated design condition life extension to a period as high as 40 years for straight portions of the pipes has been suggested (Neubauer \& Wadel 1983).

\section{Microstructure and property changes}

Microstructural changes developed after prolonged service at high temperature has attracted the attention of material scientists world wide for their study and

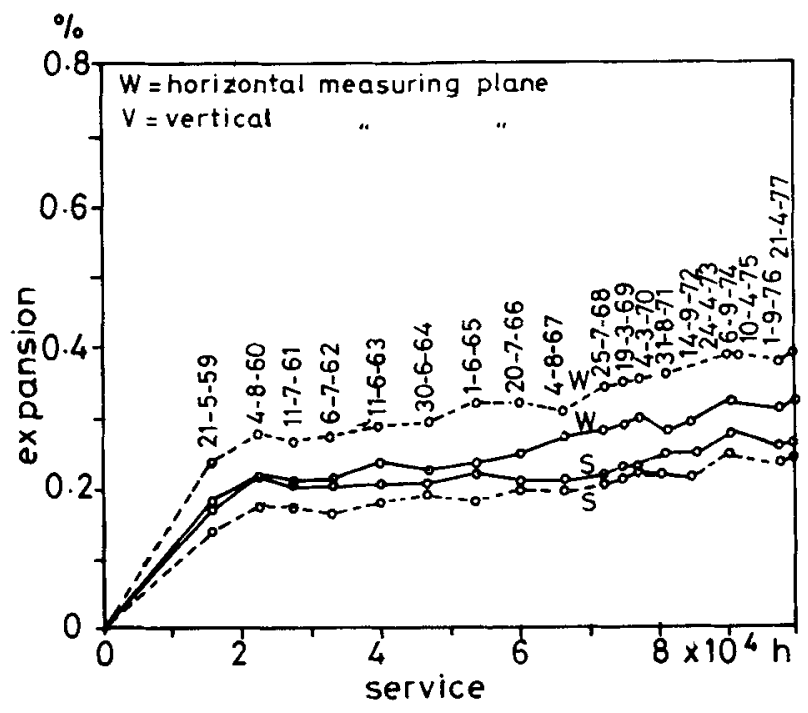

Figure 3. Expansion of intermediate superheater line of $1 \mathrm{Cr}-0.5 \mathrm{Mo}, 398 \quad$ (OD) $\times$ $18 \mathrm{~mm}$ wall, temperature $=530^{\circ} \mathrm{C}$ (Weber 1993). 


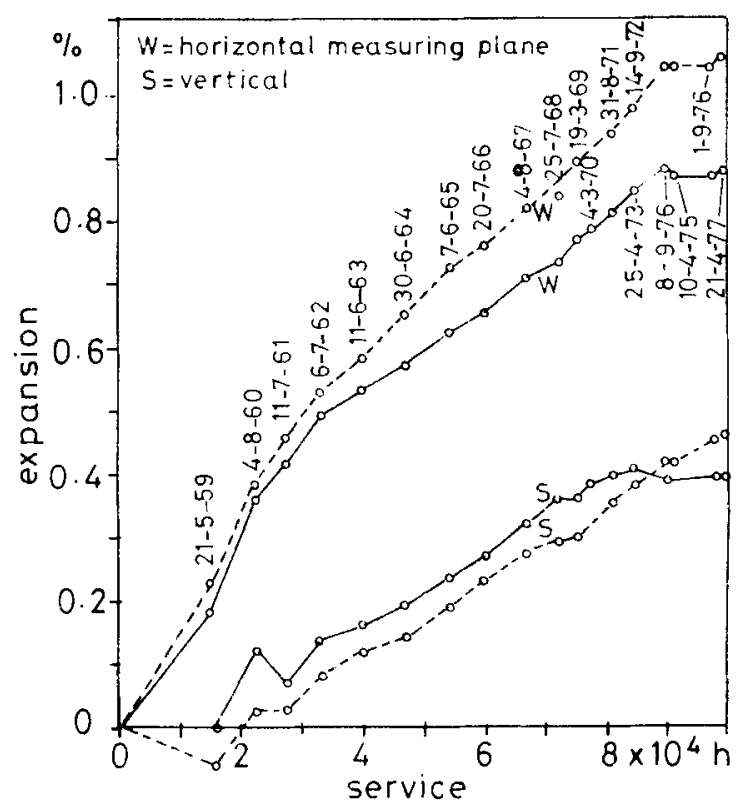

Figure 4. Expansion of life steam line of $1 \mathrm{Cr}-0.5 \mathrm{Mo}, 318$ $\mathrm{OD} \times 40 \mathrm{~mm}$ wall, temperature $=530^{\circ} \mathrm{C}($ Weber 1983$)$.

characterization can be a very attractive tool for remaining life assessment. Though information available (Foldina et al 1973; William \& Wilshire 1981; Senior 1988; Singh $\&$ Banerjee 1991) is sizeable, the goal has so far been elusive.

The changes in microstructure mainly consist of coarsening of carbides, compositional and morphological changes in the carbides, increase in the inter-particle spacing formation of new carbides, grain coarsening etc. Here, it is noteworthy that creep damage after prolonged service exposure in the form of grain boundary cavities has rarely been reported in so far as $\mathrm{Cr}-\mathrm{Mo}$ and $\mathrm{Cr}-\mathrm{Mo}-\mathrm{V}$ steels are concerned. It appears there exists a critical strain limit for initiation of grain boundary cavities. According to one report (Weber \& Wellnitz 1993), the limits are: $3 \%$ for $2-25 \mathrm{Cr}-1 \mathrm{Mo}, 2 \%$ for $1.25 \mathrm{Cr}-0.5 \mathrm{Mo}$ and $1 \%$ for $0.5 \mathrm{Cr} \cdot 0.5 \mathrm{Mo}-0.25 \mathrm{~V}$ as well as $12 \mathrm{Cr}-\mathrm{Mo}-\mathrm{V}$ steels.

Post-exposure samples have been tested by a number of workers (Cane $\&$ Townsend 1983; Weber 1983; Nakashiro et al 1990; Singh \& Banerjee 1991) and some typical results are reported in figures $5 \& 6$. One interesting fact transpires: indeed there is degradation in the rupture strengths of the service-exposed sample but this occurs up to a certain stress level. At low stresses (long-term rupture strengths) virgin and service exposed materials are hardly distinguishable. Even milder degradation has recently been reported (Cheruvu 1989) in case of turbine rotors where service temperatures are quite lower.

NML experience is also by and large in conformity with the above observation as will be seen later.

\section{NML's experience with boiler and steam pipe}

The author, jointly with other team members, has investigated over the last two decades a large number of tube failures received from various steam power plants in the country. Also, a sizeable number of samples have been investigated for health assessment and life extension. 

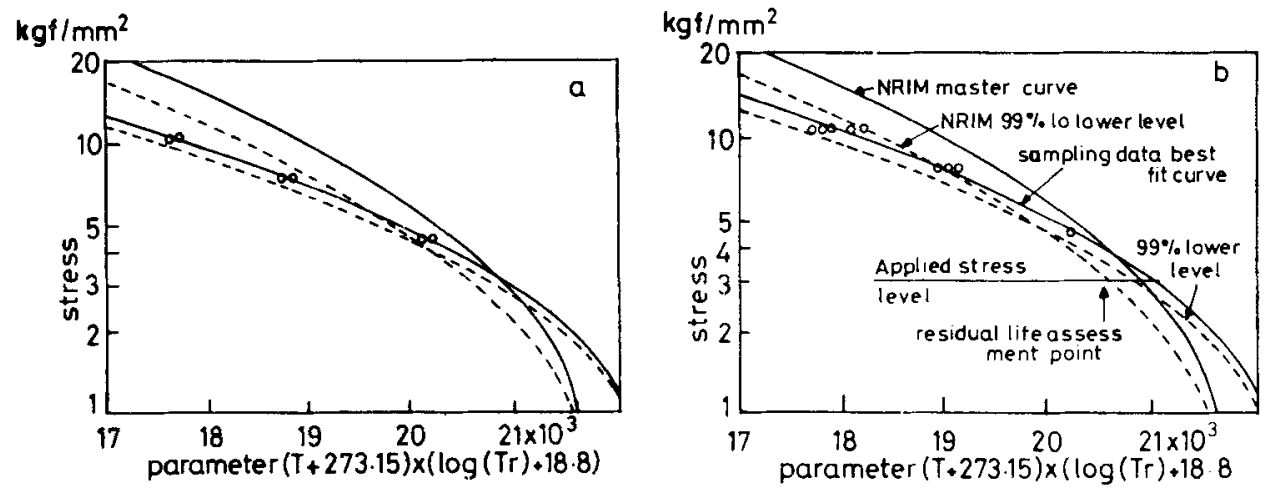

Figure 5. Stress vs Larson-Miller parameter curve of superheater tube $(2 \cdot 25 \mathrm{Cr}-$ 1 Mo steel) after 111,940 and 175,562 hour service at plant (Nakashiro 1990).

Premature failure of tubes in the different zones of boilers such as that of steam generators, superheaters and reheaters were found to have occurred due to a variety of reasons; a summary has been reported (Singh 1993). Overheating is indeed an important factor leading to premature failures which could be grouped under two categories:

- short-term excursion of runaway nature, and

- long-term excursion of temperature.

The majority of failures belonged to be first category and only a few to the second. This indirectly suggests that in the design creep has been adequately taken care of and also that the situation calls for the full exploitation of 'safe life'.

Samples for remaining life assessment and life extension recently received at NML are summarised in table 4 . Accelerated stress-rupture tests, metallographic examination and also other tests did not show any major sign of degradation after ten years of service.

Notwithstanding that a lot of information on life assessment and extension studies is available in the literature, often they are too fragmented to get a complete picture. That

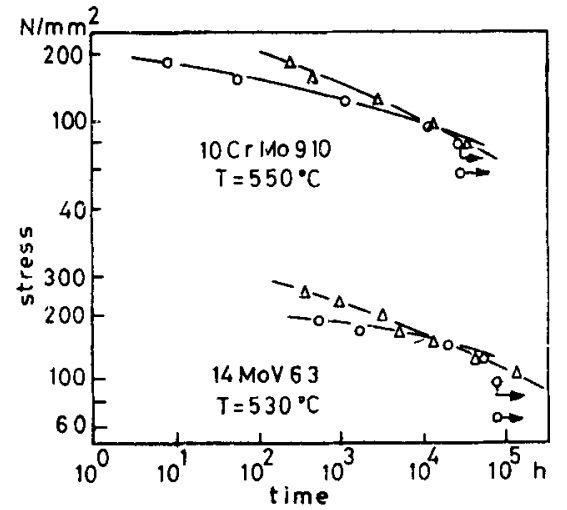

Figure 6. Creep isotherms with $(O)$ and without $(\Delta)$ service exposure, main steam pipe of $1 \mathrm{Cr}-0.3 \mathrm{Mo}-0.25 \mathrm{~V}$ steel (Weber 1983). 
Table 4. Samples for life extension recently investigated at NML.

\begin{tabular}{|c|c|c|c|}
\hline Sample & Source & $\begin{array}{l}\text { Steam value/ } \\
\text { exposure } \\
\text { ('/atm/years) }\end{array}$ & $\begin{array}{l}\text { Recornmended } \\
\text { remaining life }\end{array}$ \\
\hline $\begin{array}{l}\text { Main steam pipe } \\
1 \mathrm{Cr}-0.3 \mathrm{Mo}-0.25 \mathrm{~V}: 8 \text { Nos. } \\
273(\mathrm{OD}) \times 22 \mathrm{~mm} \text { thick }\end{array}$ & NLC & $540 / 90 / 10$ & $10^{5}$ \\
\hline $\begin{array}{l}\text { Reheater } \\
2 \cdot 25 \mathrm{Cr}-1 \mathrm{Mo}\end{array}$ & Korba & $550 / 35 / 10$ & $10^{5}$ \\
\hline $\begin{array}{l}\text { Superheater } \\
1 \mathrm{Cr}-0.3 \mathrm{Mo}-0.25 \mathrm{~V}\end{array}$ & SAIL & $450 / 40 / 10$ & $10^{5}$ \\
\hline $\begin{array}{l}\text { Heater tube } \\
1.25 \mathrm{Cr}-0.5 \mathrm{Mo}\end{array}$ & IPCL & $600 / 7 / 11$ & $10^{5}$ \\
\hline $\begin{array}{l}\text { CCU reactor } \\
\text { C-Mn }(\text { ASTM } 201) \\
300(\text { OD }) \times 23 \mathrm{~mm} \text { thick }\end{array}$ & BPCL & $480 / 2 \cdot 1 / 35$ & $10^{5}$ \\
\hline $\begin{array}{l}\text { Catalytic reforming tube } \\
5 \mathrm{Cr}-0.5 \mathrm{Mo} \\
219 \text { (OD) } \times 16 \mathrm{~mm} \text { thick }\end{array}$ & $10 C$ & $500 / 5 / 20$ & $10^{5}$ \\
\hline
\end{tabular}

Abbreviations: NLC Neyveli Lignite Corporation; SAIL - Steel Authority of India Ltd; IPCL - Indian Petrochemicals Corporation Ltd.; BPCL - Bharat Petrochemicals Corporation Ltd; IOC Indian Oil Corporation.

is comprehensive information like microstructure, mechanical properties, creep-rupture properties etc., for a specific type of steel in both virgin and service-exposed states is hardly available. Hence, a strong need was felt by the author to carry out a systematic study covering all these aspects: Post-exposure analyses of microstructural changes as well as that of degradation in creep strengths and ductilities over wide ranging stresses/temperatures, changes in hardness, room and elevated temperatures and tensile properties. A brief account of the work which led to the proposal of a new life prediction methodology based on threshold stress concept is presented.

\section{Experimental}

The new method for creep life prediction being proposed in this paper is based on a systematic study carried out on a sample of the main steam pipe of $1 \mathrm{Cr}-0.3 \mathrm{Mo}-$ $0.25 \mathrm{~V}$ steel. Experimental details and findings have been reported in other papers (Singh \& Banerjee 1991, 1992). However, a brief summary may be in order here.

Microstructural changes encountered during long-term creep exposure and their adverse impact on creep properties have been central to the most of the $R \& D$ work in the field. But useful conclusions can be derived only when both the creep and the microstructural aspects are simultaneously and extensively studied using a proper mix of samples. The study is a unique attempt to meet this objective since it is extensively devoted to:

- detailed study of the morphological and compositional changes of the carbides in both virgin and service-exposed samples (Singh \& Banerjee 1990, 1991); 
Fable 5. Details of the $1 \mathrm{Cr}-0.3 \mathrm{Mo}-0.25 \mathrm{~V}$ steel samples investigated.

\begin{tabular}{|c|c|c|c|}
\hline Sample & State/dimension & Heat treatment ${ }^{*}$ & $\begin{array}{l}\text { Microstructure/ } \\
\text { hardness }\end{array}$ \\
\hline \multirow[t]{2}{*}{ VN } & Virgin pipe & $\begin{array}{l}\text { Commercially } N \text { at } \\
980+T \text { at } 700\end{array}$ & $\begin{array}{l}90 \% \text { ferrite } 10 \% \\
\text { bainite } 156\end{array}$ \\
\hline & $273 \mathrm{~mm} \mathrm{OD} \times$ & & \\
\hline Sl: & $22 \mathrm{~mm}$ thick & Same as VN & $90 \%$ ferrite 152 \\
\hline RHV1 & $15 \mathrm{~mm}$ dia & austenitized & $100 \%$ bainite 210 \\
\hline RHV2 & $15 \mathrm{~mm} \mathrm{dia}$ & $\begin{array}{l}N \text { at } 980^{\circ} \mathrm{C}(1 \mathrm{~h})+\mathrm{T} \\
\text { at } 700^{\circ} \mathrm{C}(2 \mathrm{~h})\end{array}$ & $\begin{array}{l}80 \% \text { ferrite } 190 \\
20 \% \text { bainite }\end{array}$ \\
\hline RHV3 & $15 \mathrm{~mm} \mathrm{dia}$ & $\begin{array}{l}\mathrm{N} \text { at } 980^{\circ} \mathrm{C}(1 \mathrm{~h})+\mathrm{T} \\
\text { at } 700^{\circ} \mathrm{C}(72 \mathrm{~h})\end{array}$ & $\begin{array}{l}80 \% \text { ferrite } 160 \\
20 \% \text { tempered bainite }\end{array}$ \\
\hline
\end{tabular}

*N - normalized; $\mathbf{T}$ - tempered

- extensive creep-rupture and hot tensile properties of samples having widely varying microstructures including the one produced in the service exposed material.

The details of the five samples that have been studied are given in table 5 . The chemical composition is reported in table 6.

The SE samples are removed from the region close to the boiler end which had seen the highest service temperature. It is remarkable that the VN and the SE samples belonged to the same manufacturing batch.

Our findings of microstructural study (Singh \& Banerjee 1990, 1991) have brought out a significant point that morphological and compositional changes of the carbides impair the creep only at high stresses where the Orowan Bowing is a dominant creep deformation mechanism. On the other hand, creep strength at low stresses customarily experienced by engineering components is not affected appreciably.

The main findings concerning the creep and hot tensile studies which have provided the basis for the new approach are discussed subsequently.

\section{The threshold stress}

The threshold stresses for the five different microstructures were obtained using the Lagneborg-Bergman (1976) approach. This is schematically shown in figure 7 wherein the creep data are plotted in the form of the fourth roots of the minimum creep rates $(\varepsilon)^{0.25}$ vs the applied stresses, $\sigma$. Line 1 corresponds to the low stress sensitivity $(n=4)$ obtained at lower stresses and line 2 corresponds to the high stress sensitivity $(n \gg 4)$ obtained at higher stresses. The extension of line 2 to a strain rate equal to zero gives

Table 6. Chemical composition ( $w t \%$ ) of the pipe investigated.

\begin{tabular}{lcccccccc}
\hline $\mathrm{C}$ & $\mathrm{Mn}$ & $\mathrm{P}$ & $\mathrm{S}$ & $\mathrm{Si}$ & $\mathrm{Cr}$ & $\mathrm{Mo}$ & $\mathrm{V}$ & $\mathrm{N}$ \\
0.11 & 0.30 & 0.01 & 0.007 & $\mathbf{0 . 3 5}$ & 1.01 & 0.28 & 0.23 & 0.023 \\
\hline
\end{tabular}




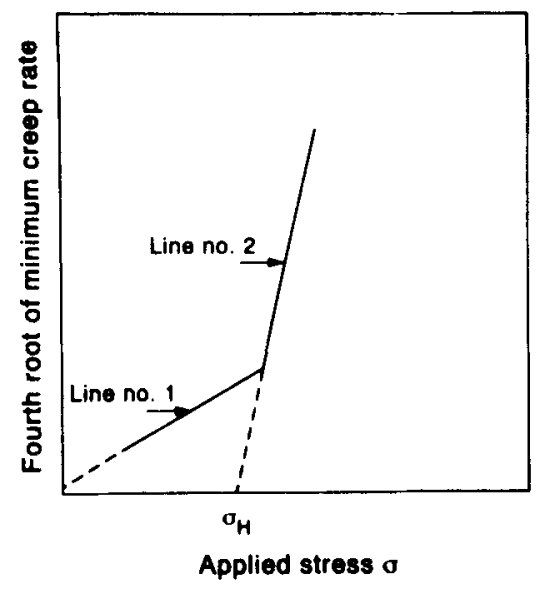

Figure 7. Schematic representation: Determination of threshold stress from creep data for a given microstructure.

the value of the threshold stress $\sigma_{H}$. The threshold stress obviously implies that it is the highest value of the applied stress which if exceeded produces runaway creep (high vaue of $n$ ).

Figure 8 shows $(\dot{\varepsilon})^{0.25}$ vs $\sigma$ plot in the high and in the low stress sensitivity regions for each of the five microstructural states. The intercepts of the lines A, B, C, D and E with the abscissa give the values of $\sigma_{H}$. The transition stress, $\sigma_{T}$, represents the stress level above which change in creep deformation mechanism is believed to occur (Lagneborg \& Bergman 1976; Blum \& Reppich 1985).

The figure shows the following important points:

- The values of $\sigma_{H}$ for the VN and the SE samples differ only by $12 \mathrm{MPa}$, which means that a service exposure of $10^{5} \mathrm{~h}$ produces only a mild degradation. This observation was also in keeping with the insignificant micro structural changes observed after an exposure of $10^{5}$ in service (Singh \& Banerjee 1991).

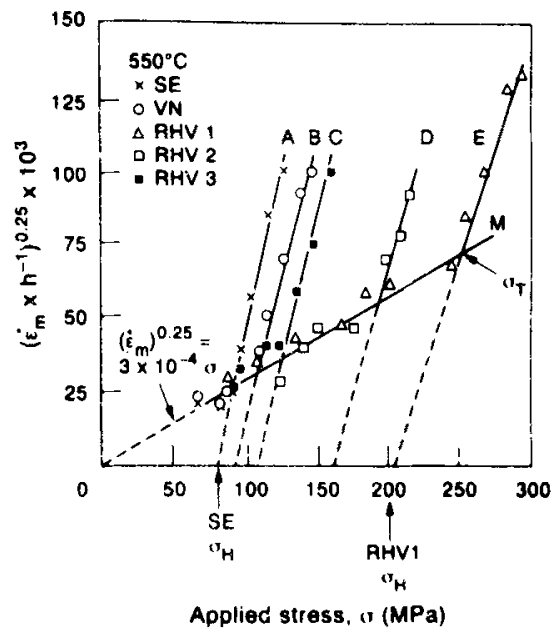

Figure 8. Threshold stress for different microstructures in $1 \mathrm{Cr} 0.3 \mathrm{Mo} 0.25 \mathrm{~V}$ steel. (Singh \& Banerjee 1992). 


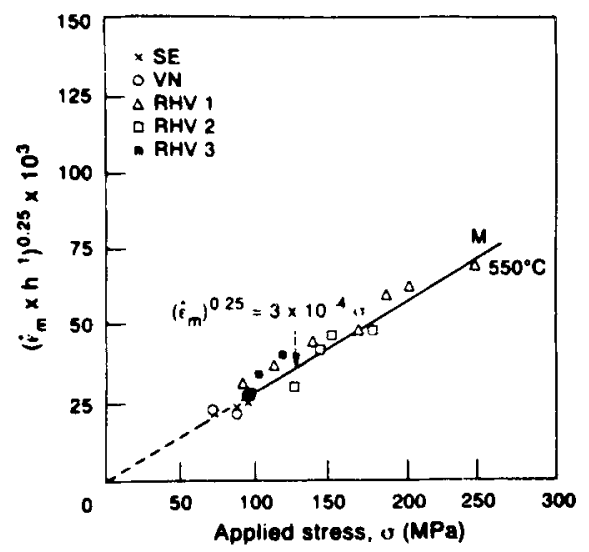

Figure 9. Minimum creep rate in the low stress sensitivity region (Singh \& Banerjee 1992).

- The creep strength varies significantly with change in original microstructures but only at higher stresses. When $\sigma<\sigma_{T}$ the data points for all microstructures fall on the same line $O M$.

- The best fit line OM (see figure 9) passes through the origin. The equation of the line OM is:

$$
(\dot{\varepsilon})^{0.25}=\mathrm{M} \sigma,
$$

where

$$
M=3 \times 10^{-4},(h)^{0.25} / \mathrm{MPa} .
$$

It may be noted that the line $\mathrm{OM}$ is microstructure-independent and hence can be used for any given microstructure for life prediction. It is also noteworthy that the $2.25 \mathrm{Cr}-$ 1 Mo steel (Wolf 1990) exhibited a similar trend (figure 10). However, the difference in respect of lower values of $\sigma_{H}$ and $M$, may be noted. This is understandable in view of the lower creep strength of $2 \cdot 25 \mathrm{Cr}-1 \mathrm{Mo}$.

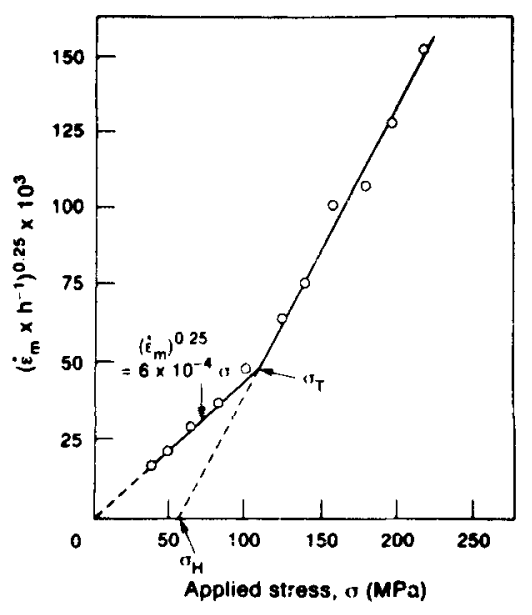

Figure 10. Threshold stress of $2.25 \mathrm{Cr}-1 \mathrm{Mo}$ steel based on published data (Wolf 1990). 


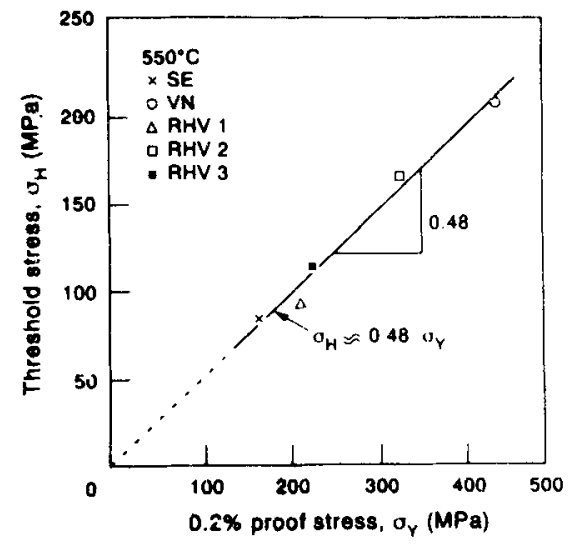

Figure 11. Threshold stress vs hot yield stress at $550 \mathrm{C}$ (Singh \& Bancrjee 1992).

\section{Correlation of $\sigma_{\mathrm{H}}$ with hot yield strength}

$\sigma_{H}$ can indicate the extent of microstructural change during creep exposure. It has also been contended that $\sigma_{H}$ "can be used as a design-limiting strength property" (Russel et al 1985). Notwithstanding this contention, it should be noted that to achieve significantly long life, the stress level in a power plant component used in high temperature service, must be considerably lower than $\sigma_{H}$. On the other hand, $\sigma_{H}$ represents an upper-bound value of the permissible stress. Indeed, the service stress at any point of time must always be less than $\sigma_{H}$ to avoid runaway creep deformation. Therefore, a simple experimental method to determine $\sigma_{H}$ should be useful. The metallographic methods to determine $\sigma_{H}$ are difficult to carry out and liable to yield uncertain results (Cane \& Townsend 1983).

Hence, the correlation of $\sigma_{H}$ with the hot tensile yield strength, $\sigma_{Y}$ as observed by us is significant. This is plotted in figure 11 , which indicates that

$$
\sigma_{H}=0.48 \sigma_{Y}
$$

Similar observation has been made on Ni-base superalloys (Russel et al 1985) where $\sigma_{H}=0.7 \sigma_{Y} ;$ Purushothaman \& Tien (1978) have also theoretically predicted the tensile rowan stress and found that it is nearly equal to $\sigma_{H}$. This indicates that the threshold stress is nearly equal to the Orowan stress and is proportional to the hot yield strength. Also, it can decrease to a lower limit of about one-half of hot yield strength, as temperature increases and/or strain rate decreases (Purushothaman \& Tien 1978).

\section{Conclusions}

Procedure for creep life prediction

Based on the main findings as represented by (1) and (2) the following steps can be suggested for a rapid assessment of the remaining creep life of a component made of $1 \mathrm{Cr}-0.3 \mathrm{Mo}-0.25 \mathrm{~V}$ steel and subjected to the usual service temperatures of $550^{\circ} \mathrm{C}$ (barrings accidental short-term excursion to a higher temperature).

(1) Determine the hot yield strength, $\sigma_{Y}$, at the service temperature and estimate $\sigma_{H}$ from the relationship $\sigma_{z}=0.48 \sigma_{Y}$. 
(2) Determine $\dot{\varepsilon}_{m}$ at six stress levels, three of them between 0.4 and 0.5 times and the other three at $0 \cdot 6,0 \cdot 7$ and 0.8 times hot yield stress. The maximum duration of one such test is 1500 hours only.

(3) Plot $\left(\dot{\varepsilon}_{m}\right)^{0.25}$ vs $\sigma$ curve in a manner similar to that in figure 5 and determine $\sigma_{H}$.

(4) If $\sigma_{H}$ is greater than the service stress, $\sigma$, calculate the residual life in terms of the time required to produce the balance amount of strain to make up the maximum permissible strain of $1 \%$. The calculation uses the simple relationship: $\left(\dot{\varepsilon}_{m}\right)^{\mathbf{0} \cdot 25}=M \sigma$.

(5) If $\sigma_{H}$ is less than the service stress, $\sigma$, retire the component and replace it at the earliest.

At present, the total duration of creep testing using the stress-rupture approach for creep-life prediction is about $15,000 \mathrm{~h}$. This can reduce five-fold if the new approach is used. Furthermore, if (1) and (2) are fully established, creep testing can be completely dispensed with.

\section{Further study}

There is need to generate a strong database at stresses approaching the service stress of $30-60 \mathrm{MPa}$ and at several temperatures between 500 and $650^{\circ} \mathrm{C}$. This should be done for various grades of both virgin and service-exposed steels so that (1) and (2) can be fully established.

It would also be interesting to assess the lowest possible value of the threshold stress after say 20-30 years of exposure. This will reveal if $\sigma_{H}$ will ever go as low as the service stress.

Generation of data at low stresses is rather tedious and would require very close control of the temperature $\left( \pm 1^{\circ} \mathrm{C}\right)$ and LVDTS with improved stability and sensitivity.

\section{References}

Auerkan 1983 Remanent creep life estimation of old power plant steam piping systems Int. Conf. on Adv. in Life Prediction Methods (eds) D A Woodford, J R Whitehead (New York: ASME) pp. $353-356$

Blum W, Reppich B 1985 Creep behaviour of crystalline solids. Progress in creep and fracture (eds) B Wilshire, R W Evans (Swansea: Univ. College) vol. 3

Cane B J, Townsend R D 1983 Production of remaining life in low-alloy steels Flow and fracture at elevated temperatures (ed) R Raj (Metals Park, OH: ASME) pp. 279--316

Cheruvu N S 1989 Degradation of mechanical properties of $\mathrm{Cr}-\mathrm{Mo}-\mathrm{V}$ and $2 \cdot 25 \mathrm{Cr}-1$ Mo steel components after long-term service at elevated temperatures. Metall. Trans. A20: 87--97

Dooley B (ed.) 1987 Conf. Proceeding: Life extension and assessment of fossil power plants (Palo Alto, CA: EPRI)

Foldina V, Jakobove A, Prinka T, Sabotk J, 1973 Influence of microstructure on creep properties of low-alloy ferritic Cr-Mo-V steels. Proc. Conf. on creep strength in steels and alloys, (London: The Met. Soc.) pp. 230- 236

Ghosh R N, Chaudhury S, Roy N, Chattopadhyay L 1995 Sadhana 20: 331-339

Lagneborg R, Bergman B 1976 The stress/creep rate bebaviour of precipitation hardened alloys Metall. Sci. 10: $20-28$

Nakashiro M, Kihara S, Kishimoto F, Fujimori T 1990 Evaluation of long-term creep strength of $2 \cdot 25 \mathrm{Cr} \cdot 1$ Mo heat trarisfer tube in actual service stress level range. Iron Steel Inst. Jpn. Int. 30: $823-828$

Neubauer B, Wadel U 1983 Rest life estimation of creeping components by means of replicas. Int. Conf. Adv. in Life Prediction Methods (eds) D A Woodford, J R Whitehead (New York: ASME) pp. 307-313 
Purushothaman S. Tien J K 1978 Role of back stress in the creep behaviour of particle strengthened alloys. Acta Metall. 26: $519 \cdots 528$

Russel R, Jeneson R R, Tien J K 1985 Temperature and strain dependence of stress-strain behaviour in a Ni-base superalloys. Metall. Trans. Al6: 10491068

Senior B A 1988 A critical review of precipitation behaviour in $1 \mathrm{Cr}-\mathrm{Mo}-\mathrm{V}$ rotor steels. Mater. Sci. Eng. A103: 263-271

Singh R 1993 Assessment of fracture and failure. Familarisation proyramme on power plant metallurgy. NTPC, Vindhyachal Super Power Project organised by NML, Jamshedpur (ed) R Singh, pp. R1-R12

Singh R, Banerjee S 1990 Morphological and compositional changes of the carbides in a ferritic steel after long-term service exposure. Scr. Metall. Mater. 24: 1093-1098

Singh R, Banerjee S 1991 Morphological and compositional changes of the carbides in Cr-Mo-V ferritic steel. Mater. Sci. Eny. 132: 203211

Singh R, Banerjee S 1992 Resisting stress of a low alloy steel after creep exposure in service. Acta Metall. Mater. 40: 2607-2616

Viswanathan R 1989 Damage mechanism and life assessment of high temperature components. (Metals Park, OH: ASME)

Weber H 1983 Report No. 35-V, Mannesman, Germany

Weber H, Wellnitz G 1993 Assessment of creep affected materials to determine remaining service life. Proc. Int. Workshop on Power Plant Remaining Life Evaluation. Prediction. Extension and Optionization (Calcutta: ASME - Indian Chapter)

William K R. Wilshire B 1981 Microstructural instability of $0.5 \mathrm{Cr} .0 .5 \mathrm{Mo} 0.25 \mathrm{~V}$ creepresistant steel during service at elevated temperatures. Mater. Sci. Eng. 47: 151-160

Wolf $\mathrm{H} 1990$ Kriechender Legierungen NiCr22CO12Mo und 10CrMo910 BEI Konstanter und zyklischer Beanspruching. PhD thesis, Univ. of Erlangen, Nurnberg, Germany.

Woodford D A. Whitehead J R teds) 1983 Int. Conf. Adt in Life Prediction Methods (New York: ASME)

Wufee V 1983 A study of life prediction techniques for main steam pipes made of pearlitic steels in power plants in China. Int. Conf. Adv. in Life Prediction Methods(eds) D A Woodford, J R Whitehead (New York: ASME) pp. 347-351 